\title{
Antimicrobial Activity and Gas Chromatography-Mass Spectrometry (GC-MS) Analysis of Saudi Arabian Ocimum basilicum Leaves Extracts
}

\author{
Ibtisam Mohammed Ababutain (1) \\ Department of Biology, College of Science, Imam Abdulrahman Bin Faisal University, P.O. Box 1982-31441, \\ Dammam, Saudi Arabia.
}

\begin{abstract}
The present study evaluates the antimicrobial activity of Ocimum basilicum leaves extracts using well diffusion assay. Microbicidal or Microbiostatic activities were determined using (MBC or MFC) /MIC ratio. All $O$. basilicum extracts ethanol, methanol, and water possess antimicrobial activity. Methanol was the best solvent with greater inhibitory activity followed by ethanol then water against bacteria. However, all three solvents showed no difference in their inhibitory activity against yeast. The MIC and $M B C$ values were in decreasing order methanol, ethanol then water against bacteria whereas Candida albicans was more sensitive at MIC $12.5 \mu \mathrm{g} / \mathrm{mL}$ than C. tropicalis at MIC $25 \mu \mathrm{g} / \mathrm{mL}$ and MFC values were lower against $C$. albicans than C. tropicalis at $25 \mu \mathrm{g} / \mathrm{mL}$ and $50 \mu \mathrm{g} / \mathrm{mL}$, respectively in all type of solvents. The ratio of (MBC or MFC) /MIC were one to three-folds. The GC-MS result showed the presence of several important chemical compounds like terpene, steroids, phenols, esters, and fatty acids most of these compounds were reported to have an antimicrobial activity. The study indicates the importance of $O$. basilicum extracts as microbicidal agent with wide spectrum and high inhibitory properties in low concentrations. Therefore, $\boldsymbol{O}$. basilicum leaves extracts may be important in the field of antimicrobial production as alternatives to antibiotics.
\end{abstract}

Keywords: Antimicrobial activity, GC-MS Analysis, Ocimum basilicum, Antibiotics.

*Correspondence: iababutain@iau.edu.sa

(Received: 01 April 2019; accepted: 20 May 2019)

Citation: Ibtisam Mohammed Ababutain, Antimicrobial Activity and Gas Chromatography-Mass Spectrometry (GC-MS) Analysis of Saudi Arabian Ocimum basilicum Leaves Extracts, J Pure Appl Microbiol., 2019; 13(2): 823-833. doi: 10.22207/JPAM.13.2.17

(c) The Author(s) 2019. Open Access. This article is distributed under the terms of the Creative Commons Attribution 4.0 International License which permits unrestricted use, sharing, distribution, and reproduction in any medium, provided you give appropriate credit to the original author(s) and the source, provide a link to the Creative Commons license, and indicate if changes were made. 


\section{INTRODUCTION}

The discovery of antibiotics in the midnineties appears to have solved most of the common problems in microbial infections. But the risk lies in the pathological cases in which the microbes are resistant to antibiotics or develop antibiotic resistance ${ }^{1,2}$. The massive use of antibiotics in the past 80 years both appropriate and inappropriate has led to fast antibiotic resistance. Bacteria are able to resist various antibiotics through horizontal gene-transfer or mutation ${ }^{3}$. Furthermore, other bacteria are intrinsically resistant to antibiotic, for example not having antibiotics target sites or having low permeability to antibiotics ${ }^{4,5}$. The resistance mechanisms for antibiotics occur by enzymatic inactivation, site target modification, active elimination, or absorption inhibition ${ }^{6}$. Estimated report indicate that the resistance of bacteria to antibiotics and their loss of ability to treat many bacterial infections will be the first killer in year 2050, where deaths are expected to reach 10 million per year, which means they are higher than deaths due to cancer?

In fact antibiotic resistance has become the third threat to public health in the $21^{\text {st }}$ century 8 . Moreover, antimicrobial resistance causes high economic burden including high therapeutic expenses and longer hospital stay ${ }^{9,10}$. Accordingly, it is necessary to develop anti-microbial agents as an alternative to treat infectious diseases. Several studies showed that plants substances are a promising source for the discovery of novel antimicrobial agents ${ }^{11-13}$.

Lamiaceae is one of most famous medicinal family plants, contains 236 genera and about 6000 species $^{14}$. Ocimum sp. is one of the important geneses in this family; it contains about 150 species that greatly differ in their morphology, aromatic composition, essential oil content, and chemical composition ${ }^{15}$. Ocimum basilicum is an annual herb grows in different regions of the world ${ }^{16}$ and is known as Basil or Sweet Basil also named as king of the herbs ${ }^{17,18}$. This aromatic plant traditionally used as fresh or dried leaves as food flavoring, food preservative, medicinal plant and perfumery ${ }^{19-21}$. Several studies reported that Sweet Basil leave extract were able to cure various illnesses and symptoms ${ }^{22,23}$. Forthermore, Sweet Basil has activity against inflammation, viruses, bacteria and fungi ${ }^{24-26}$. It has pharmacological effects against several diseases, with great antioxidant, anticancer and anti-aging properties ${ }^{27,28}$. Moreover, basil leaves essential oils and extracts were found to be a rich source of phytochemical compounds such as chavicol, linaloon, methyl ether, estagole, eugenol, methyl eugenol, and methyl chavicol ${ }^{29-31}$.

There are no previous studies involving this microbial group in a single study using alcoholic and aqueous $O$. basilicum extracts and the antimicrobial efficiency (Microbicidal or Microbiostatic). It is also noteworthy that most previous studies have highlighted the study of essential oil of $O$. basilicum and their anti-microbial activity while the 0 . basilicum extract received less attention. Therefore, the aim of this study was to compare the antimicrobial activity of three solvents of $\mathrm{O}$. basilicum leaves extracts; ethanol, methanol and water, determine the antimicrobial efficiency and their phytochemical components.

\section{MATERIALS AND METHODS Plant material}

Ocimum basilicum L. (sweet basil) plant were purchased from a vegetable market in Dammam, Saudi Arabia. The plant was identified by Department of Biology, College of science, Imam Abdulrahman Bin Faisal University using The Herb Society of America ${ }^{32}$.

\section{Preparation of plant extracts}

Plant leaves were washed thoroughly with tap water and dried at room temperature. Dried leaves were ground to fine powder using a blender. Sixty grams of the powder plant was transferred one by one to three Erlenmeyer flasks containing $300 \mathrm{~mL}$ of distilled water, ethanol $(80 \%)$, and methanol $(80 \%)$ to obtain a final concentration of $20 \% \mathrm{~g} / \mathrm{mL}$. The mixtures were placed in a shaker at $300 \mathrm{rpm} / \mathrm{min}$ for 72 hours at $20^{\circ} \mathrm{C}$ to allow extraction of active compounds. The extract solutions were filtered with Whatman No. 1 filter paper then bacterial filters and filtrates were concentrated using an oven at $80^{\circ} \mathrm{C}$. Dimethyl Sulfoxide (DMSO) was used to re-suspend the residues to a final concentration of $20 \%$ and the flasks were sealed and kept at $4^{\circ} \mathrm{C}$ for further use ${ }^{33}$. Test microorganisms

Eight microorganisms were used three Gram positive bacteria (Staphylococcus aureus 
ATCC24213, S. aureus and Bacillus subtilis) three Gram negative bacteria (Escherichia coli ATCC25922, E. coli and Pseudomonas aeruginosa) and two yeasts (Candida albicans and Candida tropicali). Most microorganisms were obtained from King Fahd Hospital, AlKhobar, Saudi Arabia. Except $B$. subtilis was obtained from the Biology Department, College of Science, Imam Abdulrahman Bin Faisal University.

\section{Agar well diffusion technique}

Antimicrobial activity was carried out using agar well diffusion technique ${ }^{34}$. One $\mathrm{mL}$ of microorganisms cultures age 18-24 h (standard inoculums $1-2 \times 10^{8} \mathrm{CFU} / \mathrm{mL} 0.5$ McFarland standard) were transfer to Petri plates, and 15 $\mathrm{mL}$ of nutrient agar was poured into the plates. After the cultures solidified, wells sizes $5 \mathrm{~mm}$ were punched using a sterile cork borer. Each well was filled with $50 \mu \mathrm{L}$ of plant extracts; DMSO was used as a negative control, erythromycin (E15 $\mathrm{mcg}$ ) as a positive control for the bacteria and nystatin (100mg) as a positive control for the yeasts. Treated plates were placed in a refrigerator for about one hour to allow diffusion of the plant extract and controls. Then plates were incubated for 48 hours at $37^{\circ} \mathrm{C}$. Antimicrobial activity was recorded in millimeters by measuring the zones of inhibition around the wells. All experiments were performed with five replicates.

\section{Determination of Minimum Inhibitory Concentration (MIC)}

Method of Omura et al. ${ }^{35}$ was preformed to determine the Minimum Inhibitory Concentration (MIC) of the plant extracts. Two-fold dilution of the plant extracts was made with nutrient broth media using 96 well microtitre plates. Standard bacterial inoculums at the concentration of $1-2 \times 10^{8} \mathrm{CFU} / \mathrm{mL}$ were added to the wells to a final concentration of $50 \%$. Well number 11 left as positive control contain growth media and bacterial inoculum and well number 12 left as negative control contain growth media and plant extract. The MICs were read after overnight incubation at $37^{\circ} \mathrm{C}$ using a microtitre plate's reader at a wavelength of 630 $\mathrm{nm}$. All experiments were performed in three replicate.

Determination of Minimum Bactericidal and Fungicidal Concentration (MBC and MFC)

Pour plate method was used to determine the $\mathrm{MBC}$ and $\mathrm{MFC}^{36}$. From the MIC experiment concentrations that showed no bacterial growth were sub-cultured using Petri plates, and then 12 $\mathrm{mL}$ of melted nutrient agar media was poured over it and gently mixed and left to solidify. The inoculated plates were incubated at $37^{\circ} \mathrm{C}$ for 48 hours. The lowest concentration that showed no visible colonies were recorded as MBC. All experiments were performed in three replicate.

Determination of antimicrobial efficiency (Microbicidal or Microbiostatic)

The antimicrobial efficiency of the of $O$. basilicum extracts (ethanol, methanol and water) was determine by using the ratio of $\mathrm{MBC}$ or MFC/ $\mathrm{MIC}^{37}$.

Gas Chromatography-Mass Spectrometry (GCMS)

Gas Chromatography-Mass Spectrometer Model QP2010 SE (Shimadzu-Japan) with 5 Sil MS 5\% diphenyl/95\% dimethyl polysiloxane capillary column (30 meter, $0.25 \mathrm{mmID}, 0.25-\mu \mathrm{m}$ df) was used to screen the bioactive compounds of Sweet Basil plant extracts. Hundred micromilliliters of plant sample were diluted using $1400 \mu \mathrm{l}$ of DMSO. One $\mu \mathrm{L}$ of diluted sample (100/1400, V/V in DMSO) was injected in the split mode with a split ratio 1:10. For GC-MS detection, electron impact ionization system with ionization energy of $70 \mathrm{eV}$ was used. Carrier gas was pure helium (99.999\%) at a constant column flow $0.7 \mathrm{ml} /$ $\mathrm{min}$ and total flow was $10.4 \mathrm{ml} / \mathrm{min}$. Flow control mode was linear velocity of $29.6 \mathrm{~cm} / \mathrm{sec}$. Injector temperature was set at $250^{\circ} \mathrm{C}$ and ion-source temperature $250^{\circ} \mathrm{C}$. The oven temperature was programmed from $50^{\circ} \mathrm{C}$ to $300^{\circ} \mathrm{C}$, hold time was $3 \mathrm{~min}$, and total run time was $29 \mathrm{~min}$. ACQ Mode Scan range from $35 \mathrm{~m} / \mathrm{z}$ to $500 \mathrm{~m} / \mathrm{z}$ with scan speed 2500 . Chemical compounds were identified by National Institute of Standards and Technology (NIST 08) library match.

\section{Statistical analysis}

The antimicrobial activities of $O$. basilicum leaves extracts between the solvents and the microbes were analyzed using SPSS Version $23.0^{38}$ at significance $p<0.01$.

\section{RESULTS}

The antimicrobial activity of $O$. basilicum extracts (ethanol, methanol and water) was tested through the presence or absence of clear growth zones around the well. The results clarify that 
solvent type affect the inhibitory activity (Table 1). In general, the methanol extract showed the highest inhibitory activity against Gram positive bacteria and Gram negative bacteria follow by ethanol extract then water extract. However, all solvents were equal in their impact on the yeasts. The results showed that $S$. aureus and $E$. coli were resistant to the Erythromycin (E15 mcg) antibiotic

Table 1. Antimicrobial activity of $O$. basilicum leaves extracts at concentration of $20 \% \mathrm{~g} / \mathrm{mL}$ using agar well diffusion technique

\begin{tabular}{|c|c|c|c|c|c|c|}
\hline $\begin{array}{l}\text { Micro- } \\
\text { organisms }\end{array}$ & $\begin{array}{l}\text { Ethanol } \\
\text { extract }\end{array}$ & $\begin{array}{c}\text { Methanol } \\
\text { extract }\end{array}$ & $\begin{array}{l}\text { Water } \\
\text { extract }\end{array}$ & $\begin{array}{c}\text { Significance } \\
(p \leq 0.01)^{*}\end{array}$ & $\begin{array}{c}\text { Positive } \\
\text { control** }\end{array}$ & $\begin{array}{c}\text { Negative } \\
\text { control*** }\end{array}$ \\
\hline \multicolumn{7}{|c|}{ Gram positive bacteria } \\
\hline S. aureus ATCC24213 & $10.7 \pm 0.6$ & $12.4 \pm 0.6$ & $7.5 \pm 0.9$ & 0.001 & $14 \pm 1.0$ & $\mathrm{R}$ \\
\hline S. aureus & $11.5 \pm 0.5$ & $11.8 \pm 0.3$ & $11.3 \pm 0.3$ & 0.003 & $\mathrm{R}$ & $\mathrm{R}$ \\
\hline B. subtilis & $10.7 \pm 0.6$ & $13.7 \pm 0.6$ & $10.5 \pm 0.5$ & 0.001 & $20 \pm 1.0$ & $\mathrm{R}$ \\
\hline \multicolumn{7}{|c|}{ Gram negative bacteria } \\
\hline E. coli ATCC25922 & $11.5 \pm 0.3$ & $12.3 \pm 0.6$ & $10.8 \pm 0.3$ & 0.001 & $9.0 \pm 1.0$ & $\mathrm{R}$ \\
\hline E. coli & $11.8 \pm 0.3$ & $12.8 \pm 0.3$ & $11.3 \pm 0.3$ & 0.001 & $\mathrm{R}$ & $\mathrm{R}$ \\
\hline$P$. aeruginosa & $11.8 \pm 0.3$ & $12.3 \pm 0.3$ & $11.4 \pm 0.5$ & 0.002 & $10.8 \pm 0.3$ & $\mathrm{R}$ \\
\hline \multicolumn{7}{|c|}{ Yeasts } \\
\hline C. albicans & $12.6 \pm 0.3$ & $12.5 \pm 0.6$ & $12.6 \pm 0.5$ & 0.1 & $19.2 \pm 0.8$ & $\mathrm{R}$ \\
\hline C. tropicalis & $11.8 \pm 0.3$ & $11.9 \pm 0.3$ & $11.7 \pm 0.5$ & 0.006 & $17.3 \pm 1.0$ & $\mathrm{R}$ \\
\hline *Significance $(p \leq 0.01)$ & 0.00 & 0.002 & 0.00 & - & - & - \\
\hline
\end{tabular}

* $P$-values are less than 0.01 which means that there is a significant difference between the tested microbes or between the used solvents.

**Erythromycin (E15 mcg) positive control for the bacteria and Nystatin $(100 \mathrm{mg})$ positive control for the yeasts. ${ }^{* * *}$ DMSO, negative control.

Table 2. Determination of Minimal Inhibitory Concentration (MIC) $\mu \mathrm{g} / \mathrm{ml}$, Minimal Bactericidal Concentration $(\mathrm{MBC})$, Minimal Fungicidal Concentration (MFC) $\mu \mathrm{g} / \mathrm{ml}$ and their ratio of $O$. basilicum extracts

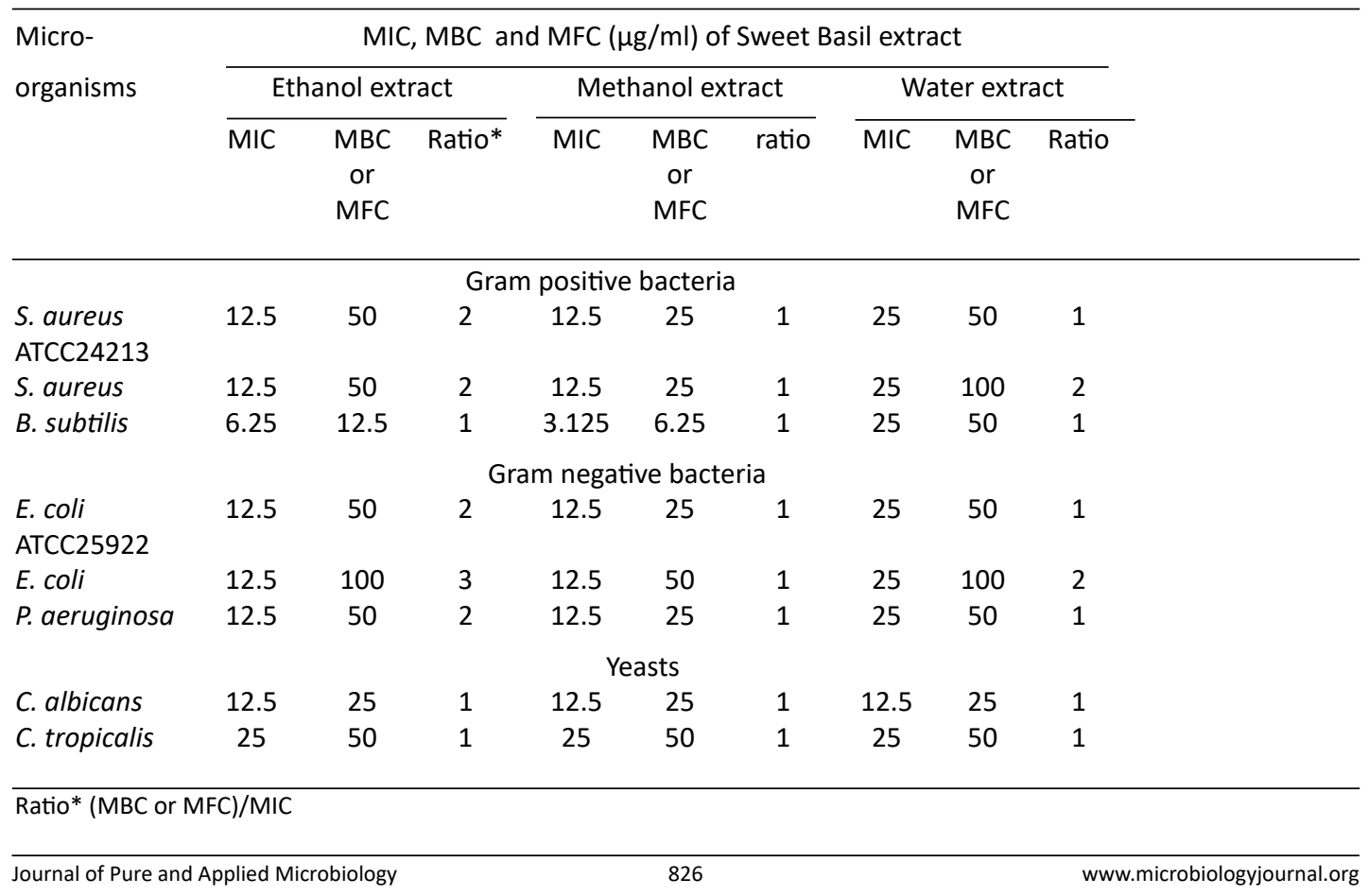




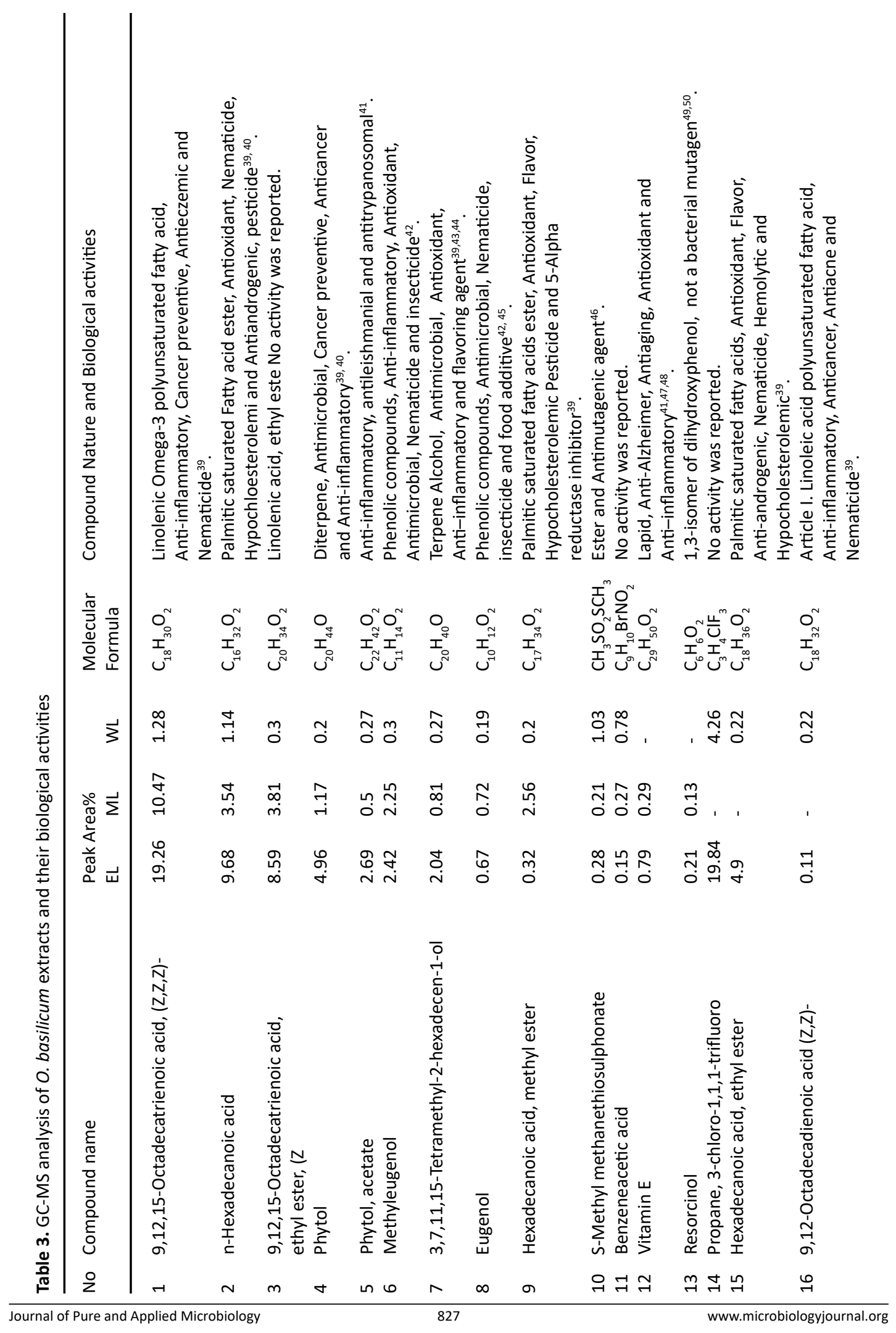




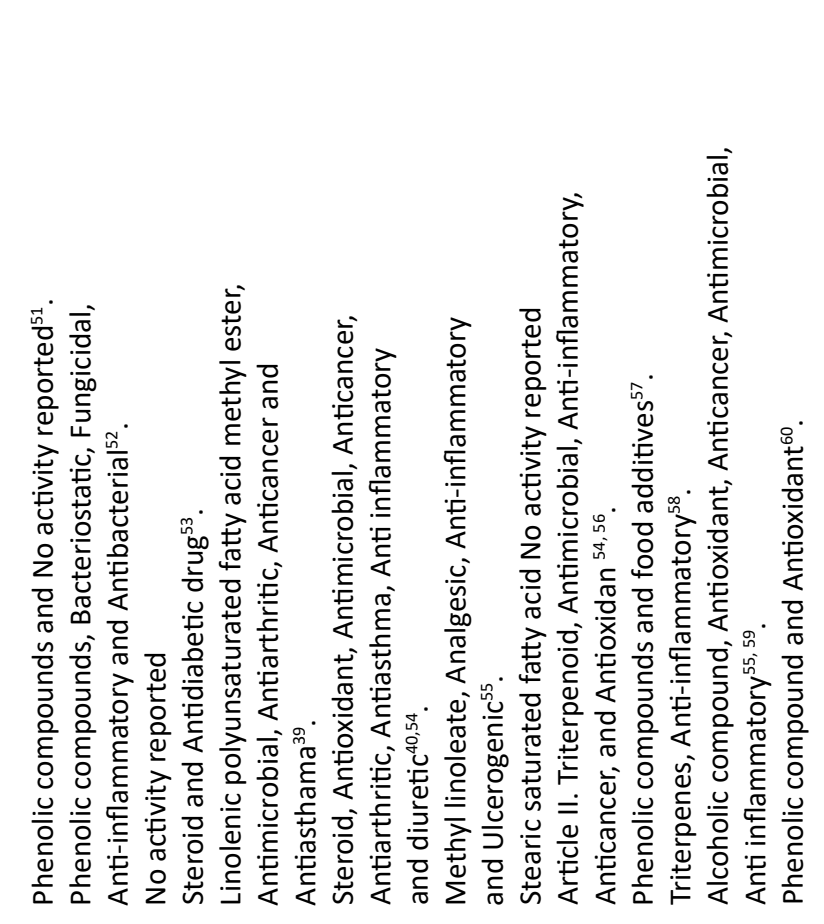

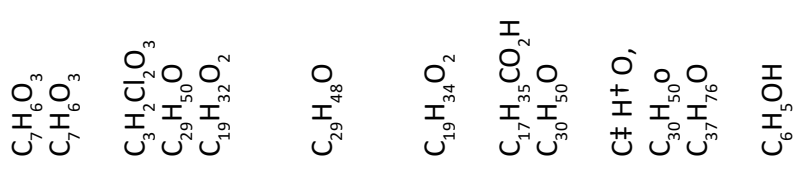

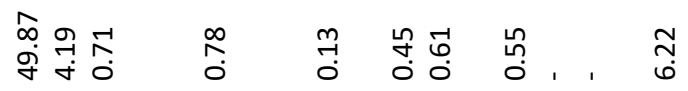

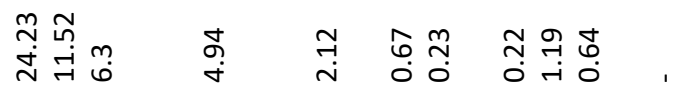

ㄴํㅇ ำ
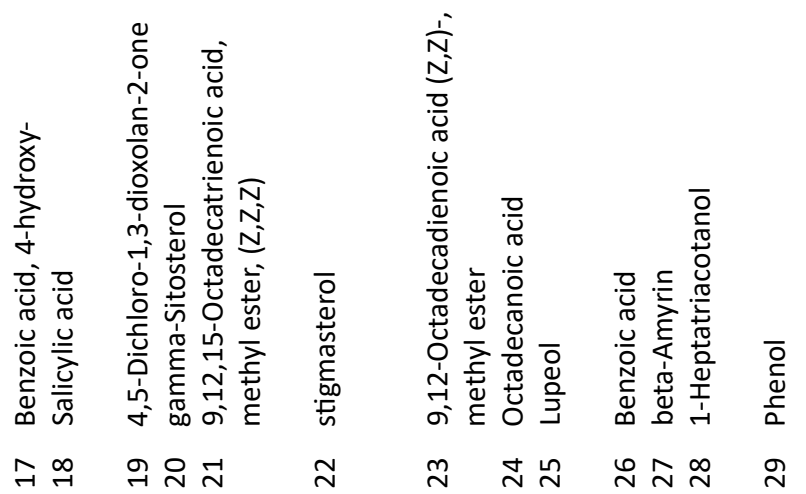
and sensitive to all $O$. basilicum extracts.

The results of MIC test showed that the widest MIC range was methanol extract from 3.125 to $25 \mu \mathrm{g} / \mathrm{mL}$ then the range became progressively narrower with ethanol extract from 6.25 to $25 \mu \mathrm{g} /$ $\mathrm{mL}$ and water extract from 12.5 to $25 \mu \mathrm{g} / \mathrm{mL}$ (Table. 2 ). B. subtilis was the most sensitive microbe to both alcoholic extracts, methanol extract with MIC $3.125 \mu \mathrm{g} / \mathrm{mL}$ and ethanol extract with MIC $6.25 \mu \mathrm{g} / \mathrm{mL}$. All three $O$. basilicum extracts had inhibitory effect on both yeasts. $C$. albicans was more sensitive at MIC $12.5 \mu \mathrm{g} / \mathrm{mL}$ than $C$. tropicalis with MIC $25 \mu \mathrm{g} / \mathrm{mL}$. MBC results showed that the ethanol extract have the highest value at $100 \mu \mathrm{g} /$ $\mathrm{mL}$ against $E$. coli also water extract against $E$. coli and S. aureus. The highest MFC value was $50 \mu \mathrm{g} /$ $\mathrm{mL}$ against $C$. tropicalis in all types of solvent compared to $25 \mu \mathrm{g} / \mathrm{mL}$ against $C$. albicans. The result showed that the maximum ratio between MIC and MBC or MFC was three-fold (Table 2).

GC-MS analysis of $O$. basilicum extracts showed total components in ethanol extract, methanol extract and water extract were 18, 23 and 23 respectively (Table 3 ). The compounds higher than $4.0 \%$ were Propane, 3-chloro-1,1,1trifluoro (19.84\%), 9,12,15-Octadecatrienoic acid, $(Z, Z, Z)-(19.26)$, n-Hexadecanoic acid (9.68\%), 9,12,15-Octadecatrienoic acid, ethyl ester, (8.59\%) and phytol (4.96\%) in ethanol extract. In the methanol extract the compounds found were 4,5-Dichloro-1,3-dioxolan-2-one $(24,23 \%), 9,12,15$-Octadecatrienoic acid, $(Z, Z, Z)-(10,47 \%)$, gamma -Sitosterol $(11,52 \%)$, $9,12,15$-Octadecatrienoic acid, methyl ester, $(Z, Z, Z)(6.30 \%)$, and stigmasterol (4.94\%). And compounds found in water extract were 4,5-Dichloro-1,3-dioxolan-2-one (49.87\%), phenol (6.22\%), Propane, 3-chloro-1,1,1-trifluoro (4.26\%) and gamma-Sitosterol (4.19\%).

\section{DISCUSSION}

Lamiaceae family contains natural bioactive components that may be considered a promising field in the discovery of new antimicrobial agents. The present study showed that all tested bacteria and yeasts exhibit sensitivities towards $O$. basilicum extracts shown by the size of inhibition zone. The results of the statistical analysis showed significant differences between the three solvents ( $p$-values $<0.01$ ), except for the effect of the solvents on $C$. albicans, which did not have significant differences ( $p$-value $>0.01$. There are also significant differences among the microbes.

This result is in regard with a previous study ${ }^{61}$ who found that water extract of $O$. basilicum inhibit the growth of both Gram positive and Gram negative bacteria. Moreover, Khalil ${ }^{62}$ reported that ethanolic extract of $O$. basilicum inhibit the growth of E. coil and S. aureus. Also, our study partly agrees with another study found that aqueous extract of $O$. basilicum have stronger inhibitory activity comparing to ethyl acetate, methanol, and $n$-hexane extracts against Gram positive and Gram negative bacteria ${ }^{24}$. It is worth noting that the $O$. basilicum extracts showed inhibitory activity against $E$. coil and $S$. aureus that were resistance to the Erythromycin (E15 $\mathrm{mcg}$ ), Indicating the superiority of the $O$. basilicum extracts on Erythromycin.

The present study showed that both yeasts were inhibited by ethanol, methanol and water extracts of $O$. basilicum this result are not consistent with a study conducted by Kaya et al. ${ }^{63}$ where they found that acetone, chloroform and methanol extracts of $O$. basilucum did not show inhibitory activity against yeasts. These differences may be due to microbial strains, growth conditions, secondary metabolites, or extraction methods. The present result indicated that methanolic, ethanolic and water extracts of $O$. basilucum posses an antifungal activity.

The present results showed differences in inhibitory capability depending on the type of solvent in which the inhibitory activity for methanol extract was higher than ethanol and water against bacteria. This result is consistent with previous studies that confirm the effect of the solvent on the inhibitory capability of plant extracts and may return to solvent polarity ${ }^{64}$, although the solvents used in this study are polar but vary in their strength in descending order water, methanol then ethanol ${ }^{65}$. In this study polar solvents have been chosen due to the ability of extracting many active compounds such as polyphenolic compounds ${ }^{66}$.

The determination of MIC and MBC or MFC is important to measure the efficiency of the plant extract as antimicrobial agents ${ }^{67}$. The 
MIC and MBC result showed that $O$. basilicum methanol extract had the lowest values of $3.125 \mu \mathrm{g} / \mathrm{mL}$ and $6.25 \mu \mathrm{g} / \mathrm{mL}$ against $B$. subtilis, respectively. In general, the present result showed that the MIC and MBC values of methanol extract are lower than those of the ethanol extract and the later are lower than the values of the water extract on the tested bacteria. This result supports the conclusion that antibacterial agents with low antibacterial activity have higher MIC and MBC values compared with more effective antibacterial agents $^{68}$. However, the result showed that yeasts respond differently to inhibitory activity of $O$. basilicum extracts where the $C$. albicans was more sensitive than $C$. tropicalis in all the extracts. Where, the values of MIC and MFC required to inhibit the $C$. albicans are higher than the $C$. tropicalis.

Antimicrobial agents are considered as Microbicidal agents if the MBC or MFC is less than four times the MIC and Microbiostatic agent if the $\mathrm{MBC}$ or MFC is more or equal than four times the $\mathrm{MIC}^{37}$. Calculation of the ratio between MIC and (MBC or MFC) is shown to be less than three-fold. Accordingly inhibiting activity of $O$. basilicum extracts may be considered as Microbicidal agent.

The current result of GC-MS analysis of $O$. basilicum extracts showed the presence of several important chemical compounds like terpene, steroids, phenols, esters, and fatty acid. These entire compounds were reported to have a variety of biological activities (Table 3 ). This result is consistent with other studies reported that O. basilicum is rich in polyphenols like Phenolic acids ${ }^{17,69}$. It is interesting that the current study is not consistent with Murali and Prabakaran ${ }^{27}$ whom found that $O$. basilicum methanol extract contains 13 compounds that did not resemble the chemical compounds found in this study. This may be due to the difference in the environment in which the plant is grown, the age of the plant or the extraction method.

The current study showed that the alcoholic and water extracts of O. basilicum were able to inhibit the growth of bacteria and yeast alike, and this may be due to the richness of $O$. basilicum with Phenolic compounds like Eugenol, Methyleugenol, Benzoic acid, Benzoic acid 4-hydroxy-, Salicylic acid, and Phenol. Phenolic compounds were reported to have several mechanisms of action against microbes, including changing the permeability of microbial cell membrane through accumulation of hydrophobic groups in the phospholipids bilayer disrupting the membrane integrity and leading to leakage of intracellular components and finally cell death. Also Phenolic compounds can bind to the enzymes inhibiting their functions like proteins, DNA and RNA synthesis ${ }^{70,71}$. Also the results showed that the O. basilicum extract contains terpene compounds like Phytol, 3,7,11,15-Tetramethyl-2-hexadecen-1ol, Lupeol and beta-Amyrin that have an effect on microbial cell membranes by disrupting membrane efficiency.

Additionally, the antimicrobial activity may be related to the presence of fatty acids. The current result showed that 0 . basilicum extract were rich in saturated fatty acid and unsaturated fatty acid both are with long carbon chain 16 and more (Table 3). McGaw et al. ${ }^{72}$ reported that Gram negative bacteria are less susceptible to fatty acids than Gram positive bacteria. Moreover, they reported that fatty acids carbon chain lengths play a very important role in their antimicrobial activity. Fatty acids containing 6 and less carbons inhibit Gram negative bacteria whereas Gram positive bacteria is inhibited by fatty acids with carbon chains longer than 12 and yeasts inhibited by fatty acids containing between 10 to 12 carbons. Several studies reported that unsaturated fatty acids with long carbon chains like linolenic acid, linoleic acid, and oleic acid have bactericidal effect on Methicillin-resistant Staphylococcus aureus, Helicobacter pylori, and Mycobacteria, while saturated fatty acids with long carbon chain like stearic acid and palmitic acid, are less active $\mathrm{e}^{73-75}$. However, the primary molecular target of fatty acid is still unknown.

\section{CONCLUSIONS}

The current study showed that $O$. basilicum extracts have a broad inhibitory spectrum against Gram negative bacteria, Gram positive bacteria and yeast. The results showed that the $O$. basilicum extracts were able to inhibit E. coil and S. aureus that were resistant to Erythromycin (E15 mcg). Moreover, the results of the determination of the inhibitory efficiency showed that $O$. basilicum extracts possesses microbicidal properties. The results also showed 
that the type of solvent is important in increasing the inhibitory capacity especially against the bacteria. The results of GC-MS showed that O. basilicum extracts are rich in compounds like Phenolic acids, fatty acid and terpene with inhibitory properties against wide range of microorganisms. The results of this study may provide new information on the importance of $O$. basilicum extracts in the production of broadspectrum anti-microbial agents with micro-bicidal properties that are environmentally friendly, have no side effects compared to antibiotics and low cost.

\section{ACKNOWLEDGMENTS}

The author would like to thank the research units at Al Rayyan campus - College of Science-Imam Abdulrahman Bin Faisal University for providing place and devices which were required for this experiment. And also like to thank Dr. Ahmed Alsayyah, Dr. Reem AlJindan, and Msr. Nouf Alromaihi for providing us with the tested microorganisms. Finally, we also like to thank Dr. Mariem Zouch for her assistant in the Statistical analysis.

\section{FUNDING}

None

\section{DATA AVAILABILITY}

All datasets generated or analyzed during this study are included in the manuscript.

\section{ETHICS STATEMENT}

This article does not contain any studies with human participants or animals performed by any of the authors.

\section{REFERENCES}

1. Lockhart S.R., Iqbal N., Cleveland A.A., Farley M.M., Harrison L.H., Bolden C.B., et al. Species identification and antifungal susceptibility testing of Candida bloodstream isolates from populationbased surveillance studies in two U.S. cities from 2008 to 2011. J. Clin. Microbial., 2012; 50(11): 3435-42.

2. Fankam A.G., Kuiate J.R., Kuete V. Antibacterial activities of Beilschmiedia obscura and six other Cameroonian medicinal plants against multi-drug resistant Gramnegative phenotypes. BMC Complement Altern. Med., 2014; 14: 241.

3. Toma A., Deyno S. Overview on Mechanisms of Antibacterial Resistance. Int. J. Res. Pharma. and Bio.
Sci., 2015; 2(1): 27-36.

4. Yoneyama H., Katsumata R., Antibiotic resistance in bacteria and its future for novel antibiotic development. Biosci. Biotechnol. Biochem., 2006; 70: 1060-75.

5. Wise R.A review of the mechanisms of action and resistance of antimicrobial agents. Can. Respir. J., 1999; 6: S20-2.

6. Soares G.M.S., Figueiredo L.C., Faveri M., Cortelli S.C., Duarte P.M., Feres M. Mechanisms of action of systemic antibiotics used in periodontal treatment and mechanisms of bacterial resistance to these drugs. $J$. Appl. Oral Sci., 2012; 20(3): 295-309.

7. O'Neill J. Review on antimicrobial resistance. Tackling Drug-Resistant Infections Globally: Final report and recommendations. https://amr-review.org/sites/ default/files/160518_Final\%20paper_with\%20cover. pdf, 2016.

8. World Health Organization; Antimicrobial resistance: global report on surveillance 2014. http://www.who. int/drugresistance/documents/surveillancereport/en/

9. Founou R.C., Founou L.L., Essack S.Y. Clinical and economic impact of antibiotic resistance in developing countries: a systematic review and meta-analysis. PLOS One, 2017; 12(12): 1-18.

10. Morgan J., Meltzer M.I., Plikaytis B.D., Sofair A.N., HuieWhite S., Wilcox S., et al. Excess mortality, hospital stay, and cost due to candidemia: a case-control study using data from population-based candidemia surveillance. Infect. Control. Hosp. Epidemiol., 2005; 26(6): 540-7.

11. Bereksi M.S., Hassa|ne H., Bekhechi C., Abdelouahid D.E. Evaluation of Antibacterial Activity of Some Medicinal Plants Extracts Commonly Used in Algerian Traditional Medicine against Some Pathogenic Bacteria. Pharmacog J., 2018; 10(3): 507-12.

12. Janta1 K., Thaharn W. Antibacterial activity of medicinal plant extracts against some pathogenic bacteria causing skin diseases. RMUTT Journal, 2018; 8(1): 141-51.

13. Yunana B.T., Bukar B.B., Aguiyi J.C. In vitro and in vivo evaluation of antibacterial activity of Bridelia ferruginea extracts on some clinical isolates. J. Phytopharmacol., 2018; 7(4): 392-8.

14. Carovit-Stanko K., Petek M., Grdi a M., Pintar J., Bedekovit D., Custic M.H., Satovic Z. Medicinal Plants of the Family Lamiaceae as Functional Foods - a Review. Czech J. Food Sci., 2016; 34(5): 377-90.

15. Makri O., Kintzios S. 'Ocimum sp. (Basil): Botany, Cultivation, Pharmaceutical Properties, and Biotechnology', Journal of Herbs, Spices \& Medicinal Plants, 2008; 13(3): 123-50.

16. Cardoso N.N., Alviano C.S., Blank A.F., Romanos M.T., Fonseca B.B., Rozental S., et al. Synergism effect of the essential oil from Ocimum basilicum var. Maria Bonita and its major components with fluconazole and its influence on ergosterol biosynthesis. Evid Based Complement Alternat Med., 2016; 123(11): e65-e66.

17. Filip S. Basil (Ocimum basilicum L.) a Source of Valuable Phytonutrients. Int. J. Clin. Nutr. Diet., 2017; 3: 118-22.

18. Mohammad A., Moghaddam D. Shayegh J. Antimicrobial activity of essential oil extract of Ocimum basilicum L. leaves on a variety of pathogenic bacteria. 
J. Med. Plants Res., 2011; 5(1): 3453-6.

19. Ko K.Y., Geornaras I., Paik H., Kim K., Sofos J.N. Effects of plant-derived extracts, other anti-microbials and their combinations against Escherichia coli 0157:H7 in beef systems. J. Food Prot., 2015; 78(6): 1090-7.

20. Gyawali R., Ibrahim S.A. Natural products as antimicrobial agents. Food Control, 2014; 46: 412-29.

21. Talaat I.M., Balbaa L.K.. Physiological response of sweet basil plants (Ocimum basilicum L.) to putrescine and trans cinnamic acid. Am. Eurasian J. Agric. Environ. Sci., 2010; 8(4): 438-45.

22. Umar A., Zhou W., Abdusalam E., Tursun A., Reyim N., Tohti I. et al. Effect of Ocimum basilicum L. on cyclooxygenase isoforms and prostaglandins involved in thrombosis. J. Ethnopharmacol., 2014; 152(1): 151-5.

23. Shafique M., Khan S.J., Khan N.H. Study of antioxidant and antimicrobial activity of sweet basil (Ocimum basilicum) essential oil. Pharmacology Online, 2011; 1(1): 105-11.

24. Sani Y.A., Cyril O., Yahaya Y., Hassan U., Ibrahim L.S. Phytochemical screening, in vitro anti-bacterial and partial TLC purification of different solvents extracts of Ocimum basilicum L. GSC Biological and Pharmaceutical Sciences, 2018; 5(2): 132-8.

25. Purushothaman B., Srinivasan R.P., Suganthi P., Ranganathan B., Gimbun J., Shanmugam K.A. Comprehensive Review on Ocimum basilicum. J. Nat. Remedies, 2018; 18(3): 71-85.

26. Al-Ali KH, El-Beshbishy H.A., El-Badry A.A., Alkhalaf M. Cytotoxic activity of methanolic extract of Mentha longifolia and Ocimum basilicum against human breast cancer. Pak. J. Biol Sci., 2013; 16(23): 1744-50.

27. Murali M., Prabakaran G. Effect of different solvents system on antioxidant activity and phytochemical screening in various habitats of Ocimum basilicum L. (Sweet basil) leavas. Int. J. Zool. Appl. Biosci., 2018; 3(5): 375-81.

28. Manosroi J., Dhumtanom P., Manosroi A. Antiproliferative activity of essential oil extracted from Thai medicinal plants on KB and P388 cell lines. Cancer Lett., 2006; 235(1): 114-20.

29. Joshi R.K. Chemical composition and antimicrobial activity of the essential oil of Ocimum basilicum L. (sweet basil) from Western Ghats of North West Karnataka, India. Anc. Sci. Life, 2014; 33(3): 151-6.

30. Shirazi M.T., Gholami H., Kavoosi G., Rowshan V. Tafsiry A - Chemical composition, antioxidant, antimicrobial and cytotoxic activities of Tagetes minuta and Ocimum basilicum essential oils. Food Sci. Nutr., 2014; 2(2): 146-55.

31. Dev N., Das A.K., Hossain M.A., Rahman S.M.M. Chemical compositions of different extracts of Ocimum basilicum leaves. J. Sci. Res., 2011; 3(1): 197-206.

32. The Herb Society of America. Basil: an herb society of America guide. Kirtland, Ohio 44094; 2003.

33. Neycee M.A., Nematzadeh G.H.A., Dehestani A., Alavi M. Assessment of antifungal effects of shoot extracts in chinaberry (Melia azedarach) against 5 phytopathogenic fungi. Intr. J. Agri. Crop. Sci., 2012; 4(8): 474-77.

34. National Committee for Clinical Laboratory Standards (NCCLS). Performance Standards for Antimicrobial
Disk Susceptibility Tests. Approved Standard, NCCLS Document M2-A5, National Committee for Clinical Laboratory Standards, Wayne, Pennsylvania, USA, 1993; 13(24).

35. Omura S,. Pyl D.V.D., Inokoshi J., Takahashi Y., Takeshima Y. Pepticinnaminsnew farnesyl-protein transferase inhibitors produced by an actinomycete I. Producingstrain, fermentation, isolation and biological activity. J. Antibiot., 1993; 46: 222-8.

36. National Committee for Clinical Laboratory Standards (NCCLS). Performance Standards for Antimicrobial Disk Susceptibility Tests. Approved Standard M2-A6. National Committee for Clinical Laboratory Standards, Wayne, Pennsylvania, USA, 1997; 17(1).

37. Levison M.E., Levison J.H. Pharmacokinetics and pharmacodynamics of antibacterial agents. Infect. Dis. Clin. North Am., 2009; 23(4): 791-9.

38. IBM SPSS Statistics for Windows, Version 23.0. Armonk, NY: IBM Corp. Released 2015.

39. Sermakkani M., Thangapandian V. GC-MS Analysis of Cassia italica leaf methanol extract. Asian J. Pharm. Clin. Res., 2012; 5(2): 90-4.

40. Tyagi T., Agarwal M. Phytochemical screening and GCMS analysis of bioactive constituents in the ethanolic extract of Pistia stratiotes L. and Eichhornia crassipes (Mart.) solms. J. Pharmacogn. Phytochem., 2017; 6(1): 195-206.

41. Al-Marzoqi A.H., Hadi M.Y., Hameed I.H. Determination of metabolites products by Cassia angustifolia and evaluate antimicobial activity. J. Pharmacognosy Phytother., 2016; 8(2): 25-48.

42. Tan K.H., Nishida R. Methyl eugenol: Its occurrence, distribution, and role in nature, especially in relation to insect behavior and pollination. J. Insect. Sci., 2012; 12(1): 1-60.

43. Shibula K., Velavan S. Determination of phytocomponents in methanolic extract of Annona muricata leaf using GC-MS technique. Int. J. Pharmacog. Phytochem. Res., 2015; 7: 1251-5.

44. Jegadeeswari P., Nishanthini A., Muthukumarasamy S., Mohan V.R. GC-MS analysis of bioactive components of Aristolochia krysagathra (Aristolochiaceae). J. Curr. Chem. Pharm. Sci., 2012; 2: 226-32.

45. Nejad M., "zg nes H., Nes H, Basaran N. Pharmacological and Toxicological Properties of Eugenol. Turk. J. Pharm Sci., 2017; 14(2): 201-6.

46. Miguel V., Lestard M.E.D., Tuttolomondo M.E., Doaz S.B., BenAltabef A., Puiatti M. et al. Molecular view of the interaction of S-methyl methane-thiosulfonate with DPPC bilayer. Biochim. Biophys. Acta Biomembr., 2016; 1858(1): 38-46.

47. Shahina P., Shahzad A., Upadhyaya P., Yadav V. Gas chromatography-mass spectrometry analysis of methanolic leaf extract of Cassia angustifolia Vahl. Asian J. Pharm. Clin. Res., 2016; 9: 111-6.

48. Kumaravel S., Muthukumaran P., Shanmugapriya K. Chemical composition of Trigonella foenumg-raecum through gas chromatography mass spectrometry analysis. J. Med. Plants Stud., 2017; 5: 1-3.

49. SCCS (Scientific Committee on Consumer Safety), Opinion on resorcinol, 2010.

50. Kobayashi A., Konishi G. Synthesis and analysis of 
Resorcinol-Acetone copolymer. Molecules., 2009; 14(1): 364-77.

51. Eseyin O.A., Sattar M.A., Rathore H.A., Aigbe F., Afzal S., Ahmad A., et al. GC-MS and HPLC profiles of phenolic fractions of the leaf of Telfairia occidentalis. Pak. J. Pharm. Sci., 2018; 31(1): 45-50.

52. Madan R.K., Levitt J. A review of toxicity from topical salicylic acid preparations. J. Am. Acad. Dermatol., 2014; 70(4): 788-92

53. Tripathi N., Kumar S., Singh R., Singh C.J., Singh P., Varshney V.K. Isolation and Identification of $\gamma$-sitosterol by GC-MS from Roots of Girardinia heterophylla. OJC, 2013; 29(2): 705-7.

54. Kumar R.N., Vasantha K., Mohan V.R. GC-MS Analysis of Bioactive Components of Tubers of Ruellia tuberosa L. (Acanthaceae). Am. J. Phytomed. Clin. Ther., 2014; 2(2): 209-16.

55. Hadi M.Y., Mohammed G.J., Hameed I.H. Analysis of bioactive chemical compounds of Nigella sativa using gas chromatography-mass spectrometry. $J$. Pharmacognosy Phytother., 2016; 8(2): 8-24.

56. Saleem M. Lupeol. A novel anti-inflammatory and anticancer dietary triterpene. Cancer Lett., 2009; 285(2): 109-15

57. El-Ziney M. GC-MS Analysis of Benzoate and Sorbate in Saudi Dairy and Food Products with Estimation of Daily Exposure. J. Food Technol., 2009; 7(4): 127-34.

58. Okoye N.N., Ajaghaku D.L., Okeke H.N., llodigwe E.E., Nworu C.S., Okoye F.B. beta-Amyrin and alpha-amyrin acetate isolated from the stem bark of Alstonia boonei display profound anti-inflammatory activity. Pharm. Biol., 2014; 52(11): 1478-86.

59. Madhavan M. Phytochemical constituents of leaves of Spatholobus parviflorus a rare threatened climber of South India. Int. J. Pharmacognosy and Phytochem. Res., 2015; 7(5): 991-4.

60. Duan X.J., Zhang W.W., Li X.M., Wang B.G. Evaluation of antioxidant property of extract and fractions obtained from a red alga, Polysiphonia urceolata. Food Chem., 2006; 95: 37-43.

61. Krishnamurthy V., Chandrashekar S.C., Kumar M.S., Sagar D. Efficiency of Crude Extract of Ocimum sanctum, Ocimum gratissimum and Ocimum basilicum Leaves against Bacterial Pathogens. Int. J. Curr. Microbiol. App. Sci., 2018; 7(4): 2609-15.

62. Khalil A. Antimicrobial activity of ethanolic extracts of Ocimum basilicum leaf from Saudi Arabia. Biotech., 2013; 12(1): 61-4.

63. Kaya I., Yigit N., Benli M. Antimicrobial Activity of Various Extracts of Ocimum basilicum L. and Observation of the Inhibition Effect on Bacterial Cells by Use of Scanning Electron Microscopy. Afr. J. Tradit. Complement Altern. Med., 2008; 5(4): 363-9.

64. Ababutain I.M. Impact of solvent type on antibacterial activities of Lawsonia inermis leaves. J. Food Agric. Environ., 2015; 13(1): 51-3.

65. Hansen C.M. Hansen solubility parameters a user's handbook. CRC Press Taylot and Francis Group; 2007. J. Am. Acad. Dermatol., 2014; 70(4): 788-92.

66. Rongai D., Pulcini P., Pesce B., Milano F. Antifungal activity of some botanical extracts on Fusarium oxysporum. Open Life Sci., 2015; 10: 409-16.

67. Dalla T., Sheboun A. Evaluation of some medical plants and their extracts as feed Additives in Broiler diets on health indicators and productive performance. Tishreen University Journal Bio Sciences Series, 2014; 36(4): 49-67.

68. Shweash M., khashan A.A., Farhan Y.M., Nasser S.J. Antibacterial activity of ethanolic extract of leaves sweet basil (Ocimum basilicum) against diarrhea caused by Escherichia coli in vitro. Int. J. Sci. Nat., 2014; 5(4): 713-8.

69. G ez C.M., Souza R.O., Fischer P., Leтo M.F.M., Duarte J.A., Boligon A.A.. Evaluation of basil extract ( Ocimum basilicum L.) on oxidative, anti-genotoxic and antiinflammatory effects in human leukocytes cell cultures exposed to challenging agents. Braz. J. Pharm. Sci., 2017; 53(1): e15098.

70. Wu Y., Bai J., Zhong K., Huang Y., Qi H., Jiang Y., et al. Antibacterial activity and membrane-disruptive mechanism of 3-p-trans-coumaroyl-2-hydroxyquinic acid, a Novel phenolic compound from Pine Needles of Cedrus deodara, against Staphylococcus aureus. Molecules, 2016; 21: 1084.

71. Cowan M.M. Plant products as antimicrobial agents. Clin. Microbiol. Rev., 1999;12(4): 564-82.

72. McGaw L.J., Jnger A.K., van Staden J. Antibacterial effects of fatty acids and related compounds from plants (minireview). S. Afr. J. Bot., 2002; 68: 417-23.

73. Seidel V., Taylor P.W. In vitro activity of extracts and constituents of Pelagonium against rapidly growing mycobacteria. Int. J. Antimicrob. Agents, 2004; 23: 613-9.

74. Sun C.Q., Connor C.J., Roberton A.M. Antibacterial actions of fatty acids and monoglycerides against Helicobacter pylori. FEMS Immunol. Med. Microbiol., 2003; 36: 9- 17.

75. Farrington M., Brenwald N., Haines D., Walpole E. Resistance to desiccation and skin fatty acids in outbreak strains of methicillin-resistant Staphylococcus aureus. J. Med. Microbiol., 1992; 36: 56-60. 